\title{
Enzymatic activities and analysis of a mycelium-based composite formation using peach palm (Bactris gasipaes) residues on Lentinula edodes
}

\author{
Gabriel Goetten de Lima ${ }^{1,2^{*}} \mathbb{0}$, Zaira Chiodini Pedri Schoenherr ${ }^{3} \mathbb{0}$, Washington Luiz Esteves Magalhães ${ }^{1,4}$, \\ Lorena Benathar Ballod Tavares ${ }^{3}$ and Cristiane Vieira Helm ${ }^{4}$
}

\begin{abstract}
By seeding fungus on top of industry residues, a mycelium can grow and form a compact network structure; however, it may not develop due to lack of optimal nutrients from the substrate. Consequently, peach-palm residues can be a potential alternative; so, to test this hypothesis, this work evaluates the effect of peach-palm residues as substrate for the growth of mycelium based on Lentinula edodes. They were also supplemented with cassava bran and various sources of nitrogen-ammonium sulphate, potassium nitrate, and soy flour-to analyse its effects on its physicochemical, enzymatic activities, and thermal and mechanical properties of the final composite at 12 and 20 days of cultivation. This mycelium was able to grow at optimum source treatment conditions, which depends on the ratio of Carbon to Nitrogen, within only 12 days of inoculation. Furthermore, the enzyme activities directly correlate with the mycelium growth with optimum conditions of $\mathrm{pH}$, water activity, and moisture for L. edodes to grow having lower enzyme activities for a well-developed composite; whereas higher activities were seen for a weakly developed material, and this material demonstrates mechanical and thermal properties similar to common mycelium-based composites. Therefore, this work demonstrates that peach-palm residues can be a potential alternative for mycelium-based composite.
\end{abstract}

Keywords: Filamentous fungi, Agro-industrial residues, Mycelium foams, Enzyme properties, Hydrolytic enzymes

\section{Introduction}

The peach-palm tree, Bactris gasipaes, is culturally and economically important in Latin America, and it has been used from the inhabitants of the Amazon forest for centuries, benefitting from all of its parts (Mora-Urpí et al. 1997). Three main layers composes this tree, the external, middle, and internal sheaths; the external and middle sheaths, which protects and surrounds this tree, are highly fibrous. However, the internal layer, known

\footnotetext{
*Correspondence: ggoetten@research.ait.ie

${ }^{1}$ Programa de Pós-Graduação em Engenharia E Ciência dos

Materiais-PIPE, Universidade Federal do Paraná, Curitiba, Paraná, Brazil

Full list of author information is available at the end of the article
}

as heart-of-palm, is the edible part (Bolanho et al. 2014; Clement et al. 2016). Additionally, Brazil is the largest producer, and consumer, of heart-of-palm in the world (de Oliveira et al. 2019) with a planted area of 27,603 ha and US\$ 43 million of value of marketed production, aiming mainly to meet the country's internal demand (IBGE 2019).

The heart-of palm is mainly sold as picked or canned, with minimal process to preserve its contents that presents significant amounts of minerals (Mora-Urpí et al. 1997). However, to extract this, food source also comes with its consequences-about $90 \%$ are considered as residue (Zenni et al. 2018); for instance, the median and internal sheaths of this tree have a low degradation rate 
(Seben et al. 2012). It is generally thrown into the soil as composting, but becomes an environmental liability in the case of peach-palm residues.

Peach palm residues (Bellettini et al. 2017) are described to have a nutrient competition, mainly nitrogen, between the soil, for its composting process, and the plant. When peach-palm residues act as compost for lettuce, it leads to a lack of nitrogen availability to the plant and reduces its normal growth. In addition, authors recommend a period of maturation of these residues before composting, but such allocated time, which is between 2 and 6 months (Chang 1987; Bellettini et al. 2017), could well be undermined with alternative usages, since they are very nutritious (Helm et al. 2013).

Wood degrading fungi are commonly used to degrade lignocellulosic materials, which are categorized into white-rot, brown-rot, and soft-rot decomposition (Blanchette et al. 1994). From within the white-rot fungi order, stands out the Lentinula edodes fungus, known as "Shiitake" mushroom of the Basidiomycetes class. This fungus degrades lignocellulosic material, by producing active enzymes in a solid-state fermentation process (Elisashvili et al. 2008) that breaks down the plant cell wall, which is then used as a source of carbon and energy for its life cycle (Kües and Liu 2000).

From within the fungi structure, the mycelium form hypha and can merge with others to produce a random fibre network structure that have a few microns in diameter (Islam et al. 2017). By seeding mycelium on organic material, it can consume upon it by secreting hydrolytic enzymes (Glass 2004), and embeds them in such hyphae network that contains binding properties, which grows as an interconnecting fibrous network so as to form a composite board (Jones et al. 2017).

Mycelium-based-materials or -composites, are reported to be useful in a variety of applications (Antinori et al. 2020); such as an alternative of polystyrene foam (Abhijith et al. 2018), a material that is neither biodegradable nor compostable. These materials possess interesting properties such as low density, low energy consumption during production, biodegradable, and can grow on a wide range of substrates (Stella et al. 2017). Besides, after usage, they can be reused as animal supplement, organic fertilizer, among others (Teixeira et al. 2018).

Overall, researchers have been using such residues into natural polymers as reinforcement (Singha and Thakur 2009), to produce renewable materials with good overall properties (Ates et al. 2020). However, mycelium-based materials could be a potential alternative, as it consists on a very simple methodology (Islam et al. 2018). The most studied fungi for the formation of this material are the division from Basidiomycota which are known for branching their hyphae into cavities (Attias et al. 2020).
The growth of this structure is dependent on the fungi used (Haneef et al. 2017), directly changing the material density, thickness, and topography.

However, most of the papers presently in literature provide little in terms of fungal species, substrate composition, and additional steps of composite formation (Antunes et al. 2020). This could be related to the fact that more than half is published by co-authors affiliated with commercial companies, as stated by a previous report (Attias et al. 2020); besides, their growing process is time-consuming (Zeller and Zocher 2012).

The biochemical mechanism during fermentation and the overall properties of the composites are also needed to be studied due to the limited research focused (Antinori et al. 2020). Furthermore, since the substrate directly influences the overall properties of the composite, it is important to understand the colonization trends and a detailed description of the substrate.

So far, only one study reported the usage of shiitake as an effective mycelium-based material, using coconut powder with wheat bran as substrate, on the effect of fungi growth and mechanical properties (Matos et al. 2019). Therefore, this work investigates the effect of solid-state fermentation from $L$. edodes on peach-palm sheath fibres using three different nutrient growing feed source treatments and evaluates the amount of enzymes produced. In addition, to investigate the overall properties of the mycelium-based composite produced with the best formulation.

\section{Materials and methods}

\section{Characterization of the substrate}

The fungus Lentinula edodes (Berk.) Peglar, maintained on Castellani method (Castellani 1967), was obtained from the macro-fungi culture collection at Laboratory of Nontimber Products within the Brazilian Agricultural Research Corporation-EMBRAPA FLORESTAS (Colombo, PR, Brazil) (internal code EF 50) registered on AleloMicro database of EMBRAPA as [BRM 055640BRM stand as Brazil Microorganism (EMBRAPA)]. The isolate was cultivated and kept in Petri dishes containing potato dextrose agar (PDA) medium for 7 days, in an environmental chamber at $25^{\circ} \mathrm{C}$ in the absence of light, and after growth, was stored at $4{ }^{\circ} \mathrm{C}$.

The Bactris gasipaes, peach-palm external inedible sheaths, used in the study were collected at the region within EMBRAPA Florestas in Colombo, Brazil. The external sheaths were crushed in a Disintegrator/Chopper/Grinder (DPM Júnior, Nogueira LLC, Brazil) reaching a final length of $2.5 \mathrm{~cm}$.

The crushed sheaths were oven-dried at $60^{\circ} \mathrm{C}$ for $24 \mathrm{~h}$, followed by supplementation with cassava bran and three sources of nitrogen (ammonium sulphate, potassium 
nitrate, and cooked soy flour) (Table 1), which were autoclaved at $121{ }^{\circ} \mathrm{C}$ ( 1 atmosphere pressure) for $15 \mathrm{~min}$. An experimental design with three replications was applied at the central point, consisting of seven feed source treatments with equivalent nitrogen concentration.

After cooling, the sheathes were inoculated in two batches. The first batch was inoculated with $1 / 6$ from mycelium plate of $L$. edodes EF50 grown in PDA medium (solid inoculum), while the second batch was inoculated with $2 / 6$ from mycelium plate of $L$. edodes that was previously crushed for $15 \mathrm{~s}$ in a modified Socarean solution (Couri and Farias 1995) (liquid inoculum). Cylindrical flasks $(8.6 \mathrm{~cm}$ in diameter and $13.6 \mathrm{~cm}$ in height) were incubated using a BOD incubator (MA1415/450, Marconi Ltd, Brazil) at $25^{\circ} \mathrm{C}$, in the absence of light, for 12 and 20 days of culture for both types of inoculum.

\section{Moisture content (\%), water activity $\left(\mathrm{w}_{\mathrm{a}}\right)$, and $\mathrm{pH}$}

The moisture content was determined by the gravimetric method described by (Hermann et al. 2013). Briefly, samples were dried at $60^{\circ} \mathrm{C}$ until a constant weight was reached, and the content was calculated through the difference between the dried weight and the initial weight.

The $\mathrm{pH}$ was determined using the potentiometric method (pH meter, Tecnal) (Lutz 2005). Briefly, $1 \mathrm{~g}$ of substrate was mixed in $10 \mathrm{ml}$ of distilled water for $10 \mathrm{~min}$ and the $\mathrm{pH}$ was measured afterwards.

The water activity $\left(\mathrm{w}_{\mathrm{a}}\right)$ was obtained by the relation between the vapor pressure of the culture medium (Pm) to that of the pure water $(\mathrm{Pw})$, as described by the procedure from AOAC international (AOAC 2016). The $\mathrm{w}_{\mathrm{a}}$ values were measured by a water activity meter (3TE Aqualab series 3B, Decagon Devices Inc., USA).

\section{Enzymatic activities}

The extraction of the enzymes complexes was performed by vacuum filtration. The extracts were centrifuged and

$\begin{aligned} & \text { Table } 1 \text { Feed source treatments used in this study, } \\
& \text { the acronym follows the feed source used followed by its } \\
& \text { composition ratio, as percentage }\end{aligned}$
\begin{tabular}{llll}
\hline Sample name & Feed source (\%) \\
\cline { 2 - 4 } & $\begin{array}{l}\text { Ammonium } \\
\text { sulphate }\end{array}$ & $\begin{array}{l}\text { Potassium } \\
\text { nitrate }\end{array}$ & Soybean flour \\
& 100.0 & - & - \\
\hline A100 & - & 100.0 & - \\
P100 & - & - & 100.0 \\
S100 & - & 50.0 & 50.0 \\
P50 S50 & 50.0 & 50.0 & - \\
A50 P50 & 50.0 & 50.0 & - \\
A50 S50 & 33.0 & 33.0 & 34.0 \\
A33 P33 S34 &
\end{tabular}

maintained at $4{ }^{\circ} \mathrm{C}$. Xylanase activity was determined by the decrease of reducing sugars carried out by xylan "birchwood", as described by (Bailey et al. 1992). The enzyme activity was initiated using $0.9 \mathrm{~mL}$ sample of $1 \%$ xylan with $0.1 \mathrm{~mL}$ of the enzyme extract, and the amount of sugar decrease was measured by the 3.5-dinitrosalicylic (DNS) method (Miller 1959).

The activities of endo- $\beta$-1,4-glucanase, or carboxymethylcellulase CMC, (EC 3.2.1.4) and exo- $\beta-1,4-$ glucanase, or avicelase (EC 3.2.1.74) were determined according to the method described by (Tanaka et al. 1981). It consisted of conducting the hydrolysis of two solutions: the first was $0.44 \%$ carboxymethylcellulose solution in a buffer solution of $0.05 \mathrm{M}$ sodium acetate (pH 5.0) for the EC 3.2.1.4 fraction activity; and, in the same buffer, $1.1 \%$ suspension of microcrystalline cellulose (Avicel) for the EC 3.2.1.74 fraction. The reaction was initiated by adding $0.9 \mathrm{~mL}$ of enzymatic extract in $0.9 \mathrm{~mL}$ of substrate, which was reacted for $60 \mathrm{~min}$. The amount of reducing sugars was determined by the DNS method (Miller 1959).

$\beta$-Glucosidase activity (EC 3.2.1.21) was determined according to (Wood and Garcia-Campayo 1990). Briefly, $1 \mathrm{~mL}$ of $15 \mathrm{mM}$ cellobiose solution (diluted in sodium acetate buffer $\mathrm{pH}$ 5.0) was added into $1 \mathrm{~mL}$ of enzymatic extract, and incubated at $50{ }^{\circ} \mathrm{C}$ for $30 \mathrm{~min}$. The reaction was stopped by immersing the tubes in boiling water for $5 \mathrm{~min}$. After transferring to a cold-water bath, the glucose produced was determined using a liquid enzyme glucose Kit (Doles Reagentes Inc., Brazil) based on the glucose oxidase-peroxidase reaction.

The statistical analysis of the experimental planning was performed using multivariate analysis. The model was simplified to exclude terms that were not considered statistically significant $(p>0.05)$ by analysis of variance (ANOVA). Analysis of the feed source treatments were initially performed as independent variables for the enzymatic activities, $\mathrm{pH}$, moisture, and water activity, to assess which of the sources had a significant effect. A second-order polynomial fit was adjusted to the treatments on all variables. Pareto diagram was also obtained to investigate which of these treatments had significantly contributed to the work. All of these processes were performed using the STATISTICA software, version 8.0 (Stat Soft Inc., Tulsa, OK, USA).

\section{Qualitative analysis of microbial growth}

Through visual observation, the flasks containing fungus and cellulose fibres were determined according to the standard adapted from ASTM (American Society for Testing Materials) G21-90 (1990) (ASTM 1990), depicting the following growth ranges:

$$
\text { - (-) lack of growth. }
$$


- (+) little growth, with presence of small fragments from mycelium produced in the medium.

- $(++)$ moderate growth with the appearance of a thin pellet on the surface of the medium.

- $(+++)$ optimum growth of mycelium within half to full growth from the flask volume.

\section{Pre-compression tests}

The pre-composite formed from the best mycelial growth result (S100) was carefully removed from the flask with the help of a spatula, without breaking the structure. The compression test (ASTM 165-07) (ASTM 2017) was performed as a preliminary test, to analyse its behaviour for further studies using a universal testing machine model DL2000 and EMIC brand. After compression, these samples were oven-dried at $60{ }^{\circ} \mathrm{C}$ for $3 \mathrm{~h}$. They were further used in the next studies naming it as composite coldpressed (from S100 condition).

\section{Composite formulation}

To verify the composite integrity, the condition with the best mycelium growth was repeated using a larger mould, higher surface area, and smaller height $(350 \times 250 \times 11$ $5 \mathrm{~mm}=$ length $\times$ width $\times$ height), than the composites cold-pressed that were grown in flasks from glass. They were labelled as composite non-pressed (from S100 condition); after 12 days, samples were oven-dried at $60{ }^{\circ} \mathrm{C}$ for $3 \mathrm{~h}$.

\section{Carbon/nitrogen and ash analysis}

The percentage of carbon $(\mathrm{C})$, nitrogen $(\mathrm{N})$, sulphur $(\mathrm{S})$, and hydrogen $(\mathrm{H})(\mathrm{CHNS})$ in the samples of pure soy flour, cellulose peach-palm sheath fibres, and the mycelium-based composite were determined using an elementary analyser equipment CHNS (CHNS Elementar, model Vario MACRO Cube, Langenselbold, Hesse, Germany).

\section{Histological sections}

Histological sections were performed with a microtome (Microm GmbH, Walldorf-Germany, Type HM325). Peach palm sheath fibres and composite (formed from S100 condition) were analysed. Samples previously chopped with a maximum size of $1.0 \mathrm{~cm}$ were included in paraffin and sectioned on a rotating microtome. They were double stained with $1 \%$ astra blue and $1 \%$ safranin which were mounted on permanent slides with synthetic resin, according to the conventional techniques (Kraus and Arduin 1997). The samples were observed and analysed in the Axio imager A2 microscope.

\section{Scanning Electron Microscopy (SEM)}

To observe and compare the formation of the mycelium from the fungus in the peach-palm sheath fibres,
Scanning Electron Microscopy (SEM) was used. Small samples from the composites (formed from S100 condition) and pure peach-palm sheaths were covered using a gold sputtered equipment. For the mycelium-based composite, the equipment used was a Shimadzu-SSX-550 Superscan; whereas for the pure sheath fibres, a Hitachi TM-1000 was used.

\section{Compression test}

Three samples from the mycelium-based composite were cut to the following dimensions $60 \times 60 \times 20 \mathrm{~mm}^{3}$ and followed the ASTM 165-07 (ASTM 2017) standard. The compression tests were performed with a universal testing machine brand EMIC, model DL 2000. A load cell of 2 tons was used for the test.

\section{Water absorption and swelling}

Since the composites are hydrophilic, the water absorption capacity and the swelling of the composite were evaluated. The standard procedure used for water absorption was the ASTM D-570 98 (ASTM D570-98 2018) and the EM 317 for swelling (British Standards Institution BSI 1993).

Specimens of dimensions from $20 \times 20 \times 20 \mathrm{~mm}^{3}$ were cut from the mycelium-based composite. The material was weighed and measured before and after each period, to determine the percentage of water absorption and swelling at constant temperature $23{ }^{\circ} \mathrm{C}$. The specimens were immersed in water for a period of 2,24 , and $48 \mathrm{~h}$.

\section{Thermal analysis (DTG and DSC)}

The stability of peach-palm sheath fibres, and the composites, were investigated by thermogravimetric analyses (TG). The equipment DTG-60H-Shimadzu was used for TG/DTA and DSC-60A was used for DSC technique, using about $5 \mathrm{mg}$ of each sample. The heating rate was $10{ }^{\circ} \mathrm{C} / \mathrm{min}$ until reaching $600{ }^{\circ} \mathrm{C}$, in a nitrogen atmosphere at $20 \mathrm{~mL} / \mathrm{min}$, and for the DSC, aluminium pans were used.

\section{Results and discussion}

Moisture content $(\%)$, water activity $\left(\mathrm{w}_{\mathrm{a}}\right)$, and $\mathrm{pH}$

Physico-chemical analysis of the feed source treatments related to the growth of fungus (Fig. 1) presents different profiles and efficiencies. The time period used in this study had initial $\mathrm{pH}$ values ranged from 3.65 to 5.65 for all treatments (Fig. 1i, ii). The highest $\mathrm{pH}$ values occurred using pure soy flour, for both inoculum; also, significant differences occurred for all pure treatments. Nonetheless, treatments containing potassium nitrate and ammonium sulphate had lower $\mathrm{pH}$ values, which can be observed by their surface contour profiles (Fig. 1vii and Additional file 1: Fig. S1A), and is related to their higher dosage. For 


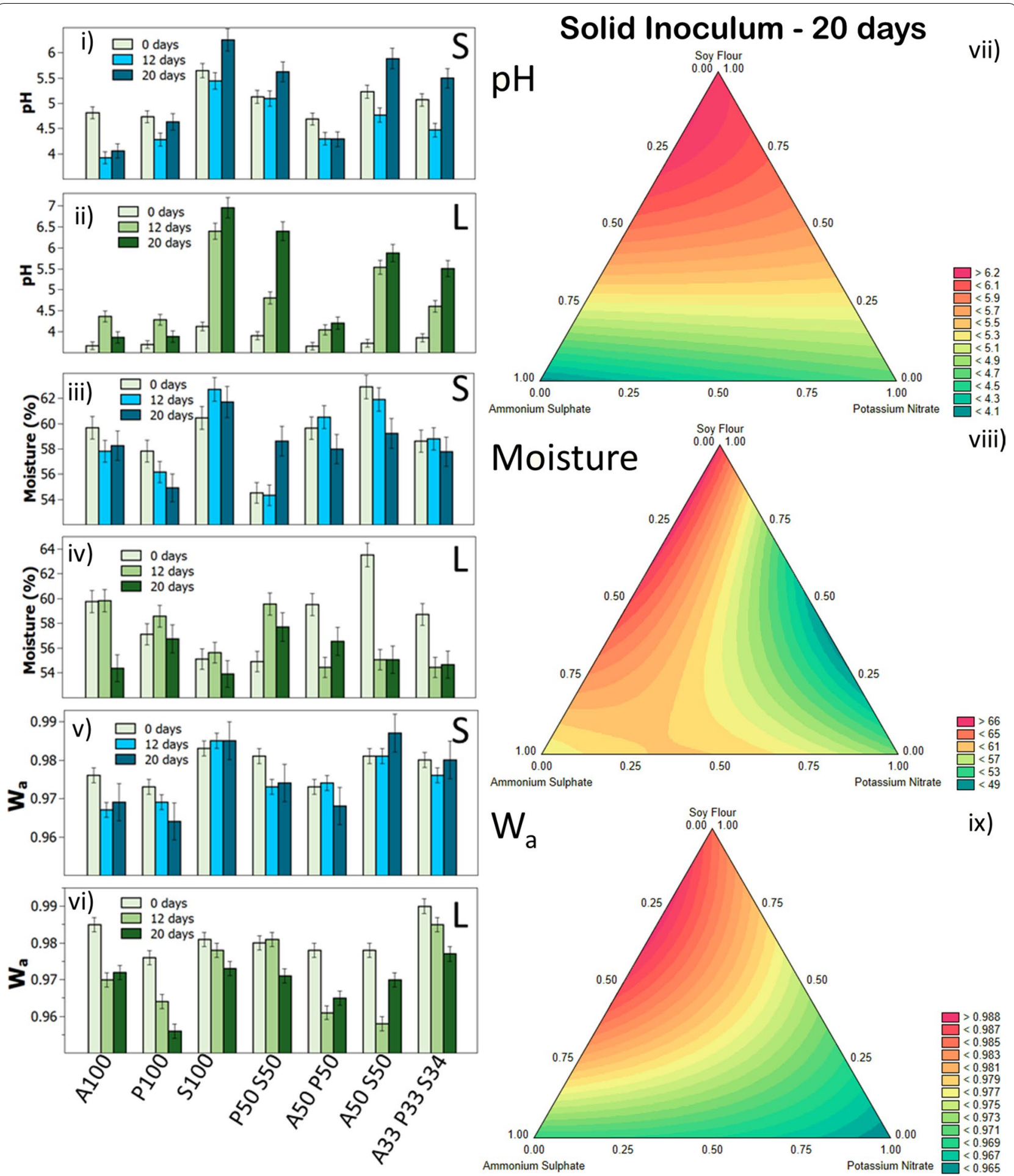

Fig. 1 Physico-chemical results in the studied time periods for $\mathrm{pH}$, moisture, and water activity for solid (i, iii, v) and liquid (ii, iv, vi) inoculum, with their specific surface contour plot relating to a solid inoculum (vii-ix) at 20 days

the highest $\mathrm{pH}$ region, they were located near the corners of the treatments containing soy flour source, similar to a previous report (Hermann et al. 2013).
Some species of basidiomycetes have a self-regulating $\mathrm{pH}$ characteristic, with a tendency to stabilize at an optimum $\mathrm{pH}$ value for their growth, regardless of the initial 
pH value (Mata et al. 2016; Chicatto et al. 2018); therefore, it might be the reason for the $\mathrm{pH}$ growth in feed source treatments containing soy flour. Nonetheless, treatments without soy flour had lower $\mathrm{pH}$, and it further decreases with time compared to their initial values. This could be inferred to the ratio content of carbon nitrogen which may impart the mycelium growth; so, the $\mathrm{pH}$ of the medium does not self-regulate and the fungus cannot control the environment as it occurred at $\mathrm{pH}$ above 5.0 (Carvalho et al. 2018).

Samples moisture varied slightly depending on the treatment source used-ranging between 54 and $62 \%$ (Fig. 1iii, iv), similar to another report using $L$. edodes for solid-state fermentation (Bentolila de Aguiar et al. 2013), a condition favourable for the growth of the fungus. Consequently, the culture media must not have low relative moisture, since the water content is essential for the growth and metabolism of $L$. edodes (Antunes et al. 2020). Nonetheless, the results reported a decrease in moisture after the last cultivation time interval, for the majority of the samples, also detected in another work (Hermann et al. 2013); whereas the treatment containing only soy flour had the highest moisture content (58-60\%). In a well-developed mycelium, it is possible to obtain precise values of moisture, but variations may occur depending on the fungus strain and treatments used.

The surface contour plot exhibits (Fig. 1viii) that treatments containing highest moisture was found for higher concentration of soy flour; though for the time period of 12 days and liquid inoculum (Additional file 1: Fig. S2A), the region with the highest values was found within a well-balanced source of soy flour and potassium nitrate.

For the water activity values $\left(\mathrm{w}_{\mathrm{a}}\right)$ (Fig. $1 \mathrm{v}$, vi), all feed source treatments exhibited activities greater than 0.955 , and they were increased at the final studied time period for the majority of the treatments. These values are reported to be within a region for optimum fungus growth (higher than 0.950) (Pandey et al. 2000), which is also an indicative of large water available for the microorganism to develop.

The majority of the treatments presented to be significant in regards to their physico-chemical profiles.
Increased values was perceived for the mixture of soy flour and ammonium sulphate for solid inoculum; while for liquid inoculum, optimum values were obtained for soy flour with potassium nitrate (Additional file 1: Fig. S3A-S6).

\section{Moisture content $(\%)$, water activity $\left(\mathrm{w}_{\mathrm{a}}\right)$, and $\mathrm{pH}$ of the mycelium-based composites}

The physico-chemical characteristics of the myceliumbased composites exhibit some differences in the process performed (Table 2). The moisture exhibited to be positive for the growth of the fungus-as expected-and the low values are related to the drying methodology. Higher moisture from a more compacted material, cold-pressed, may be related to an increased difficulty of the water to be released compared to a non-pressed composite.

Nonetheless, the values of moisture content, $\mathrm{w}_{\mathrm{a}}$, and $\mathrm{pH}$ were similar to previous reports using L. edodes as solid-state fermentation biomass (Chicatto et al. 2014; Pedri et al. 2015).

\section{Enzymatic activities}

The enzymatic activities for avicelase, carboxymethylcellulose, $\beta$-glicosidase, and xylanase exhibited a similar behaviour, when comparing solid and liquid inoculum (Fig. 2). For the majority of the cases, lowest enzyme activities occurred when soy flour was used, which can also be seen with the surface contour plot (Fig. 3 and Additional file 1: Figs. S7A, S8). Contrarily, sources containing ammonium sulphate, followed by potassium nitrate, had the highest activities on all enzymes.

The composition of the substrate is an important factor for the growth and expression of various fungi, especially when the nutrients contains nitrogen and carbon. Therefore, a fungus may extract these elements more easily within a mixture of ammonium sulphate and/or potassium nitrate (Rughoonundun et al. 2012). Nonetheless, it has been reported that nitrogen is a key element in the growth of $L$. edodes (Lin et al. 2015). Therefore, an increase in organic matter content is expected where mycelium colonization is more advanced (Attias et al. 2020).

Table 2 Physico-chemical, compressive, and sorption kinetic properties of the mycelium-based composites studied

\begin{tabular}{|c|c|c|c|c|c|c|c|c|c|c|}
\hline \multirow[t]{2}{*}{ Sample } & \multicolumn{6}{|c|}{ Physico-chemical } & \multicolumn{2}{|l|}{ Compressive } & \multicolumn{2}{|c|}{ Sorption kinetics $\left(\mathrm{dH}_{2} \mathrm{O}\right)$} \\
\hline & $M_{0}(\%)$ & $M_{f}(\%)$ & $w_{\mathrm{a} 0}$ & $w_{a f}$ & $\mathrm{pH}_{0}$ & $\mathrm{pH}_{\mathrm{f}}$ & Modulus (kPa) & Strength $(\mathrm{kPa})$ & $\begin{array}{l}\text { Weight } \\
\text { increase (\%) }\end{array}$ & $\begin{array}{l}\text { Thickness } \\
\text { expansion } \\
(\%)\end{array}$ \\
\hline Cold-pressed & 60.4 & 14.1 & 0.98 & 0.50 & 5.6 & 5.8 & - & - & $245 \pm 3$ & $21.5 \pm 0.5$ \\
\hline Non-pressed & 59.7 & 8.05 & 0.99 & 0.52 & 5.8 & 6.0 & $238 \pm 16$ & $223 \pm 10$ & $351 \pm 4$ & $18 \pm 1$ \\
\hline
\end{tabular}



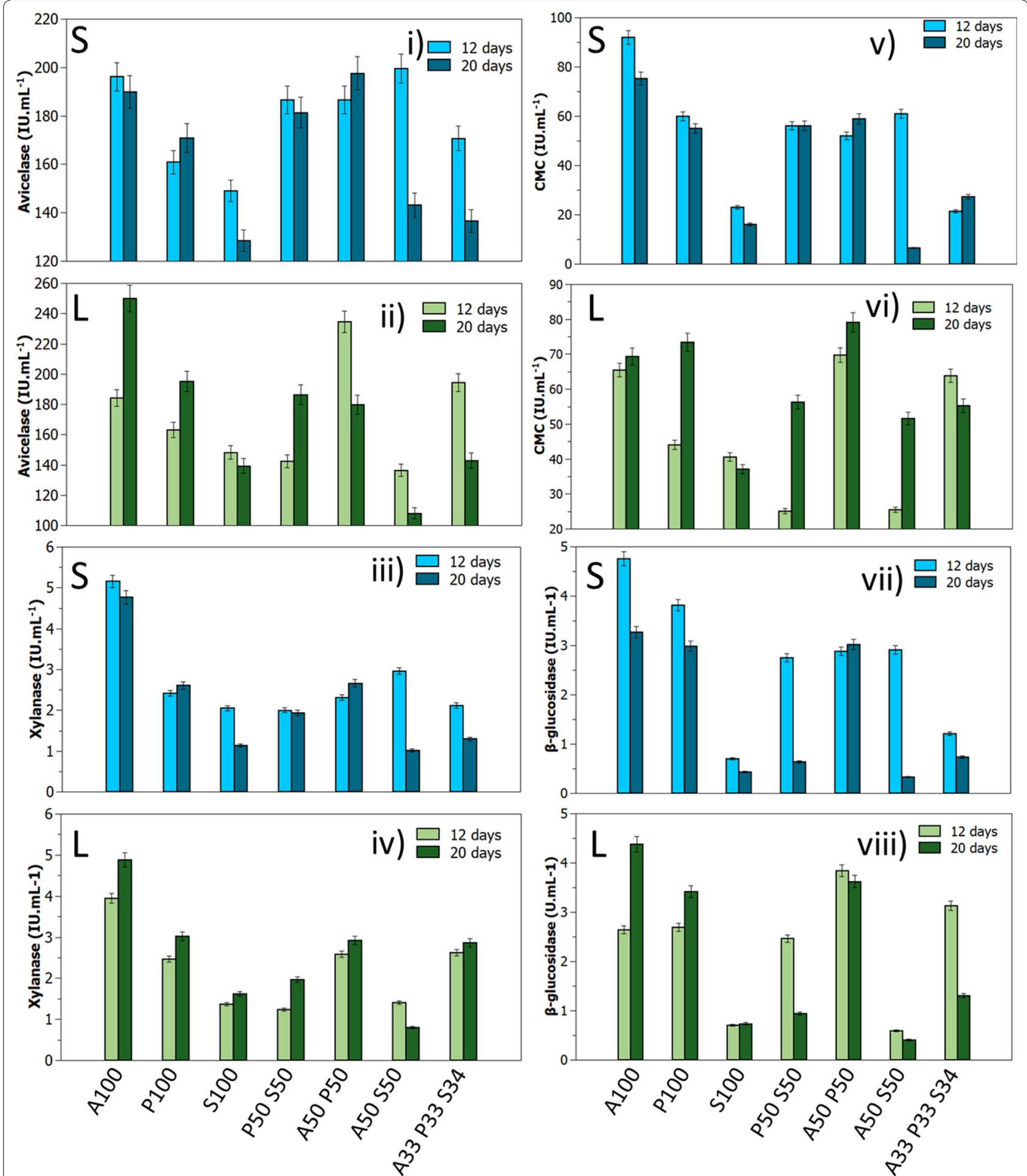

Fig. 2 Enzymatic activities of avicelase (i-ii), xylanase (iii-iv), CMC (v-vi), and $\beta$-glucosidase (vii-viii) using a solid or liquid inoculum at two studied time intervals ( 12 and 20 days)

The activities of the various feed source treatments using $L$. edodes evidenced it to be a good degrader of the peach-palm residue because of its increased enzyme activities. In addition to its nutritious for fungus growth, it is possible that, within 12 days, the majority of the growth from the mycelium might 


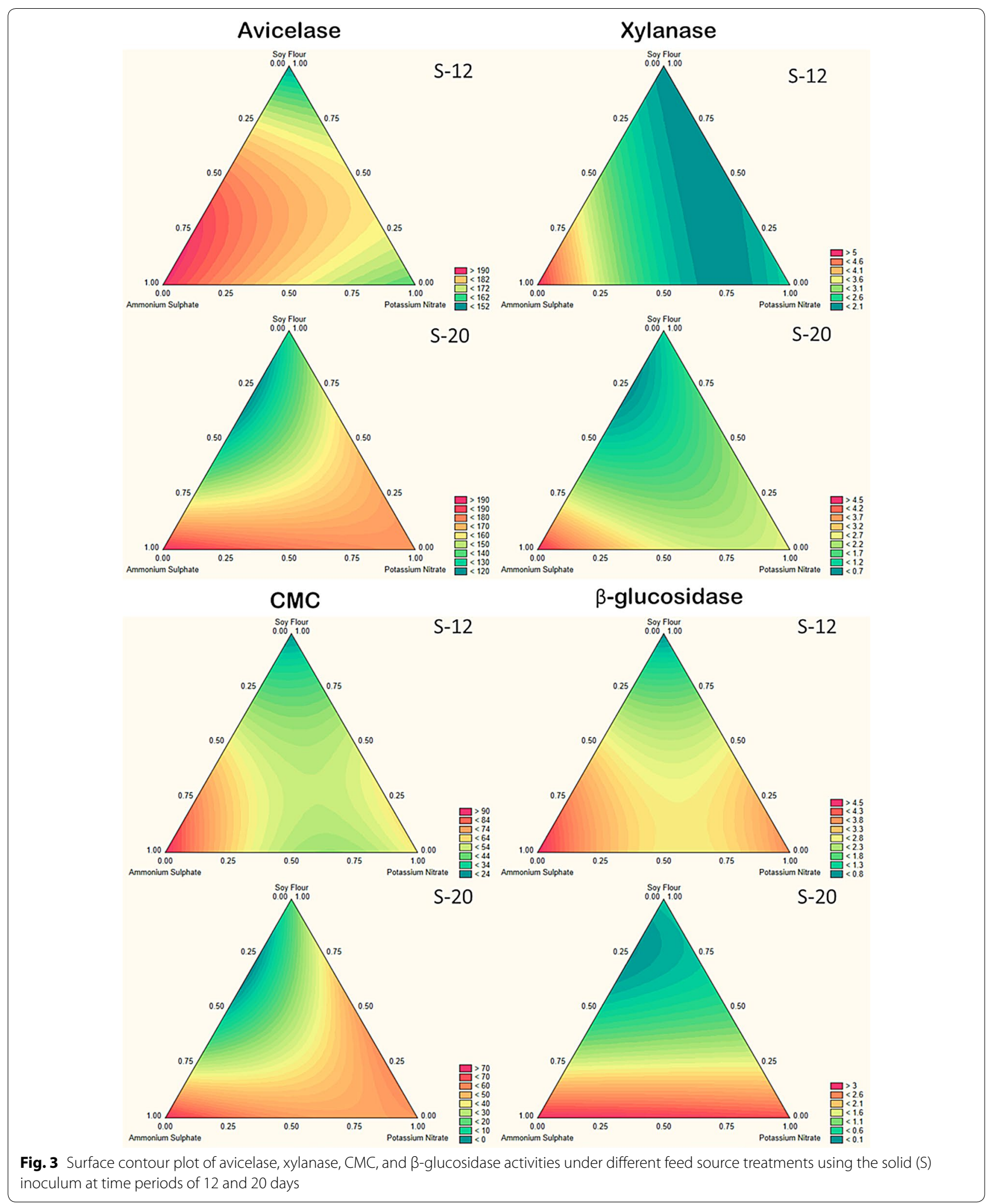


already occurred, and the trend saw within these results could be the last digestive enzymes cycles, which could be quite the opposite for the other treatments. Nonetheless, the majority of the enzyme activities presented a similar trend from a previous work that used L. edodes with solid-state fermentation (Philippoussis et al. 2011).

The presence of soy flour, which influenced a decrease in enzyme activity, may be related to the nitrogen sources (Philippoussis et al. 2011; Chicatto et al. 2018); in which higher content decreases the hydrolytic system, but induces an increase in oxidative enzymes. Nonetheless, ammonium sulphate can also be converted into proteins by microorganisms, and, although these values seems to show a direct relation, their actual profile is also dependent of the substrate used-peach-palm residues.

From within each enzyme activity, avicelase and xylanase lowest activities occurred with treatment containing soy flour, or with a mixture containing potassium nitrate (Fig. 2i, ii and iii,iv); however, it actually exhibited the highest activity for avicelase (199.46 $\left.\mathrm{UI} \mathrm{mL}^{-1}\right)$ using solid inoculum within the time period of 12 days (Fig. 2i). Apart from that, avicelase highest activities in all groups were produced in treatments with ammonium sulphate, either as pure source or with the addition of potassium nitrate (234.6 and $249.9 \mathrm{UI} \mathrm{mL} \mathrm{mL}^{-1}$, for 12 and 20 days, respectively).

For xylanase, the highest activity was found for pure sources of ammonium sulphate $\left(5.15 \mathrm{UI} \mathrm{mL}{ }^{-1}\right.$ and 4.87 $\mathrm{UI} \mathrm{mL} \mathrm{m}^{-1}$ within time period of 12 days, using solid inoculum, and 20 days using liquid inoculum respectively). Overall, the enzymatic activities' profile of avicelase and xylanase exhibits a similar behaviour when comparing the time period and the inoculum used (Fig. 3 and Additional file 1: Fig. 7a), and most of the studied sources used were statistically significant in the enzymatic activity values (Additional file 1: Fig. S9, 10).

Since peach-palm sheaths are reported to contain $19.5 \%$ of lignin on a dry basis, and are lower than other common organic residues such as soy, sugarcane bagasse, rice, and corn (Franco et al. 2019), avicelase activities produced in this study were higher than other residues using another white-rot fungi Agaricus brasiliensis, same Agaricales order of fungi from $L$. edodes (de Siqueira et al. 2010). However, low values of xylanase were found herein compared to the aforementioned residues.

For CMC and $\beta$-glucosidase enzymes (Fig. 2v-viii), the highest activities were found for treatments containing pure ammonium sulphate, or with a combination of soy flour $\left(91 \mathrm{IU} \mathrm{mL} \mathrm{m}^{-1}\right.$ and $4.7 \mathrm{IU} \mathrm{mL}^{-1}$ at 12 days using solid inoculum; also, $79 \mathrm{IU} \mathrm{mL}-1$ and $4.4 \mathrm{IU} \mathrm{mL}^{-1}$ at 20 days using solid inoculum for $\mathrm{CMC}$ and $\beta$-glucosidase respectively).
Their enzymatic profile also exhibits that, for solid inoculum (Fig. 3), ammonium sulphate region had increased activity on all time periods, and for liquid inoculum (Additional file 1: Figure S8A), potassium nitrate had a major part on CMC enzyme. For $\beta$-glucosidase enzyme activity, ammonium sulphate had a major role; though on a shorten time period, 12 days, the mixture of ammonium sulphate and potassium nitrate region had higher activity.

Lowest enzyme activity region was found within the mixture of soy flour and ammonium sulphate for the time period of 20 days, using low concentrations of ammonium sulphate (Fig. $3-\mathrm{CMC}$ and $\beta$-glucosidase); while for a shorten time period, 12 days, pure soy was the least effective on enzyme activity. However, only ammonium sulphate and potassium nitrate were able to exhibit a significant difference for $\mathrm{CMC}$ and $\beta$-glucosidase (Additional file 1: Figure S9-12).

Endoglucanase, CMC, activity is reported to be produced in moderate quantities for $L$. edodes, this could be further enhanced depending on the amount of hemicellulose (Philippoussis et al. 2011). Furthermore, variations on the cellulolytic activity have been reported for $L$. edodes which depends on the fungus growth stage (Chicatto et al. 2014). It has been reported that a deceleration in mycelium growth rates could occur after the third colonization week, leading to a decrease in the enzyme activity because of the limitation of utilizable nutrients and carbon sources (Philippoussis et al. 2011).

Ammonium sulphate, as nitrogen source for the fungus, can have positive effects for CMC and proteins, but can inhibit the production of avicelase. The $L$. edodes strain can also result in variation of the enzyme activity (de Siqueira et al. 2010). Therefore, due to differences in chemical composition of substrates for cultivation, it is important to select genotypes with suitable characteristics for growth in the existing substrate; which in turn depends on the fungus ability to utilize the majority of the substrate components as nutritive elements (Elisashvili et al. 2008). Likewise, the presence of certain compounds, such as phenolics, from the substrate could also inhibit fungus growth (Mata et al. 2016).

\section{Qualitative analysis of mycelium growth and composite formation}

The growth of $L$. edodes over time (Fig. 4) exhibits that the lowest microbial growth was observed in feed source treatments containing either pure ammonium sulphate, or potassium nitrate; also, a mixture of those two had a small formation of L. edodes mycelium in the medium.

The treatment with a mixture of all supplements, A33 P33 S34, had no mycelial growth with the liquid inoculum, for both endpoints studied herein, and this could 

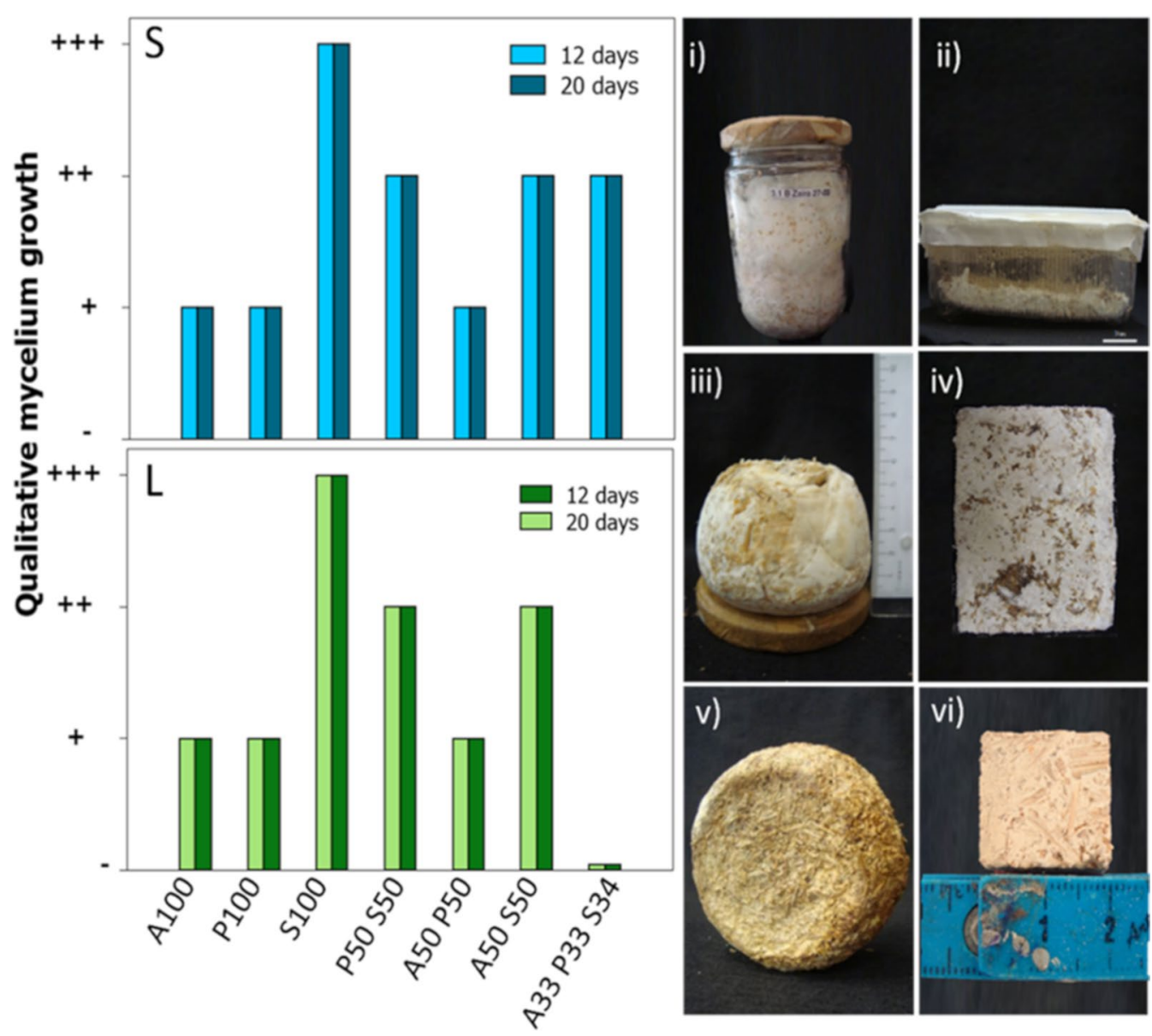

Fig. 4 Qualitative mycelium growth from the studied feed --source treatments, varying from lack to optimum at time points of 12 and 20 days using a solid (S) or liquid (L) inoculum. Also, macroscopic images of the S100 treatment (i-ii) before and (iii-iv) after mycelium-composite removal from the flask, (v) is after compression and drying (cold-pressed); (vi) oven-dried, grounded, and final piece (non-pressed)

have been due to the concentration of the elements (Helm et al. 2013). In addition to the fact that, within both time periods, the growth rates are directly related to their enzymatic activities, as discussed in previous "Moisture content (\%), water activity $\left(\mathrm{w}_{\mathrm{a}}\right)$, and $\mathrm{pH}$ of the mycelium-based composites." section.

Mixing soy flour with the other treatments had a moderate mycelial growth for L. edodes, corresponding to half of the substrate covered by a mycelium network, for both time periods. Additionally, the treatment with the highest mycelial growth was found for pure soy flour source, in both inocula, in which the fungus reached the surface of the bottle.

The enzymes released from the mycelia hyphae contributes to the mycelium-composite formation, by degrading the substrate and increasing its mycelia density (Tacer-Caba et al. 2020). It is important to remind that the yield of materials based on mycelium depends on the strain, medium, conditions of growth, and growth cycle (Philippoussis et al. 2011; Elisashvili et al. 2015; Attias et al. 2019). Nonetheless, mycelium growth of $L$. edodes is affected by substrate cellulose, hemicellulose, and lignin proportions, along with nitrogen content (Philippoussis et al. 2011).

It has been suggested that if a media is too difficult to digest, it can induce the mycelium to secrete more enzymes-having a wide and fast surface but reduced volume, an effect that occurred for sources containing mainly ammonium sulphate. This effect can be reversed if the media is rich in compounds that are easily digested by the mycelium, such as D-glucose, leading to an increase in the material volume (Antinori et al. 2020). In the case of peach-palm sheaths, they contain higher values of non-reducing and reducing sugars (Helm et al. 2013) than other common residues, such as sugarcane bagasse (Rabelo et al. 2015), and may have contributed to the further growth of this fungus. 
Therefore, due to the optimum condition for L. edodes to grow using pure soy flour, mycelium grew more than the other conditions, and what is seen by their enzymatic profile is at the end of the composite formation. This suggests that the majority of the enzyme activity, in digesting and consuming the residue, already occurred prior to the first time period observed in this study; alternatively, other sources shown higher values due to the difficulty in digesting, relating to a poor growth of the mycelium. This trend was already reported in a previous work of our group, with the usage of residues from Eucalyptus benthamii using the same fungus (Pedri et al. 2015).

The visual mycelial density, for a supplement containing pure soy flour, features a compact mycelium block on the peach-palm sheath fibres (Fig. 4i-iv), and this source preference by the fungus may be related to the presence of amino acids (Leonowicz et al. 1991). The nutritive parameters of this residue were able to produce a mycelium composite, a significant achievement by the usage of this fungus compared to substrates containing higher values of hemicellulose and nitrogen (Philippoussis et al. 2011). Nonetheless, the contents of cellulose and hemicellulose on peach-palm sheaths are lower than other common residues, such as bamboo and sugarcane (Franco et al. 2019), and lower hemicellulose content is a good indicative for mycelium development (GaitánHernández et al. 2011).

Because of the limited space found for the fungus to grow on the flask, they reached to its top, and a volume from about half the size of the flask was formed. Therefore, they were compressed to remove excess of water, and evaluate how this material would behave for future analysis.

This treatment and period, S100 and 12 days, using a solid inoculum was chosen, due to the higher mycelia growth rate within few days of cultivation. However, the liquid inoculum did not show the same characteristics of mycelial growth, as its interior was not completely colonized by the fungus, containing empty spaces, and it led it to be impossible to continue the mechanical test.

The interaction of the hyphae with the fibres formed a compact material after compression. According to the curves obtained in the test, points were estimated to determine the force and deformation (Additional file 1: Figure S13). The force was applied until the rupture of the material, which was close to $4 \mathrm{~cm}$ of deformation, and it was labelled as cold-pressed.

However, to compare this composite, a new one was produced using the same treatment of cold-pressed with a bigger size mould or flask in length. The composite-labelled as non-pressed-was able to grow evenly and detached over the days from the mould on its own (Fig. 4iii, iv); therefore, it is possible to tailor its volume based on the media and source used for the fungus to grow. In addition, the material formed within 12 days was very similar to the one formed at 20 days, and it was also the reason this time period was selected.

This material had some characteristics similar to a polystyrene presenting a rigid structure of polysaccharides (matrix) over fibres that are biodegradable and with characteristics of fibre/matrix association.

\section{Elemental analysis by CHNS}

A relation of carbon and nitrogen was analysed in the peach-palm sheaths, soy flour, and the mycelium-composite (Table 3), exhibiting that the presence of soy in the substrate had positive effects on the time and in the mycelial growth. It is already known that the addition of supplements increases the levels of nitrogen and available carbohydrates (Pedri et al. 2015).

Supplementation with flour has shown that, for the cultivation of $L$. edodes, it is necessary a source of nitrogen within the substrate (Queiroz et al. 2004). It has been reported that the $C: N$ ratio should be between 30 and 40 to favour the mycelial growth of $L$. edodes (Song et al. 1987), which indicates the relation between growth rate and availability of nitrogen. Therefore, since peach-palm sheaths already possess a relation of $\mathrm{C}: \mathrm{N}$ within a favourable growth, it is also possible that soy flour-containing the lowest amount of nitrogen than other supplementsmay have contributed to the growth of this material.

\section{Histological sections}

The microscopic images of the lateral (Fig. 5i) and transversal (Fig. 5ii) sections of the plant cell from peach-palm sheaths exhibit, on the transversal section, larger circumferences related to the sap transport duct (arrow). Like others lignocellulosic materials, peach-palm sheaths are basically composed of cellulose and lignin.

Peach palm sheaths that underwent solid-state fermentation using $L$. edodes fungi presented a similar aspect of the raw sheaths, but with traces of the soy and cassava flour (Fig. 5iii and iv). The same region examined for the pure sheaths shows that, after formation of the mycelium composite, they were further degraded, and a disorder of small fragments stands out around the fibres [arrows

\section{Table 3 Elemental analysis of the studied materials, obtained from the CHNS equipment}

\begin{tabular}{lllllc}
\hline Material $^{\mathbf{a}}$ & Carbon & Nitrogen & C:N & Sulphur & Hydrogen \\
\hline Peach palm sheaths & 40.87 & 1.14 & $42: 1$ & 0.164 & 7.33 \\
Soy flour & 54.56 & 7.59 & $8: 1$ & 0.236 & 10.41 \\
$\begin{array}{l}\text { Non-pressed com- } \\
\text { posite }\end{array}$ & 42.61 & 4.51 & $11: 1$ & 0.273 & 7.51 \\
\hline
\end{tabular}

a For all components, the results were calculated from the average 


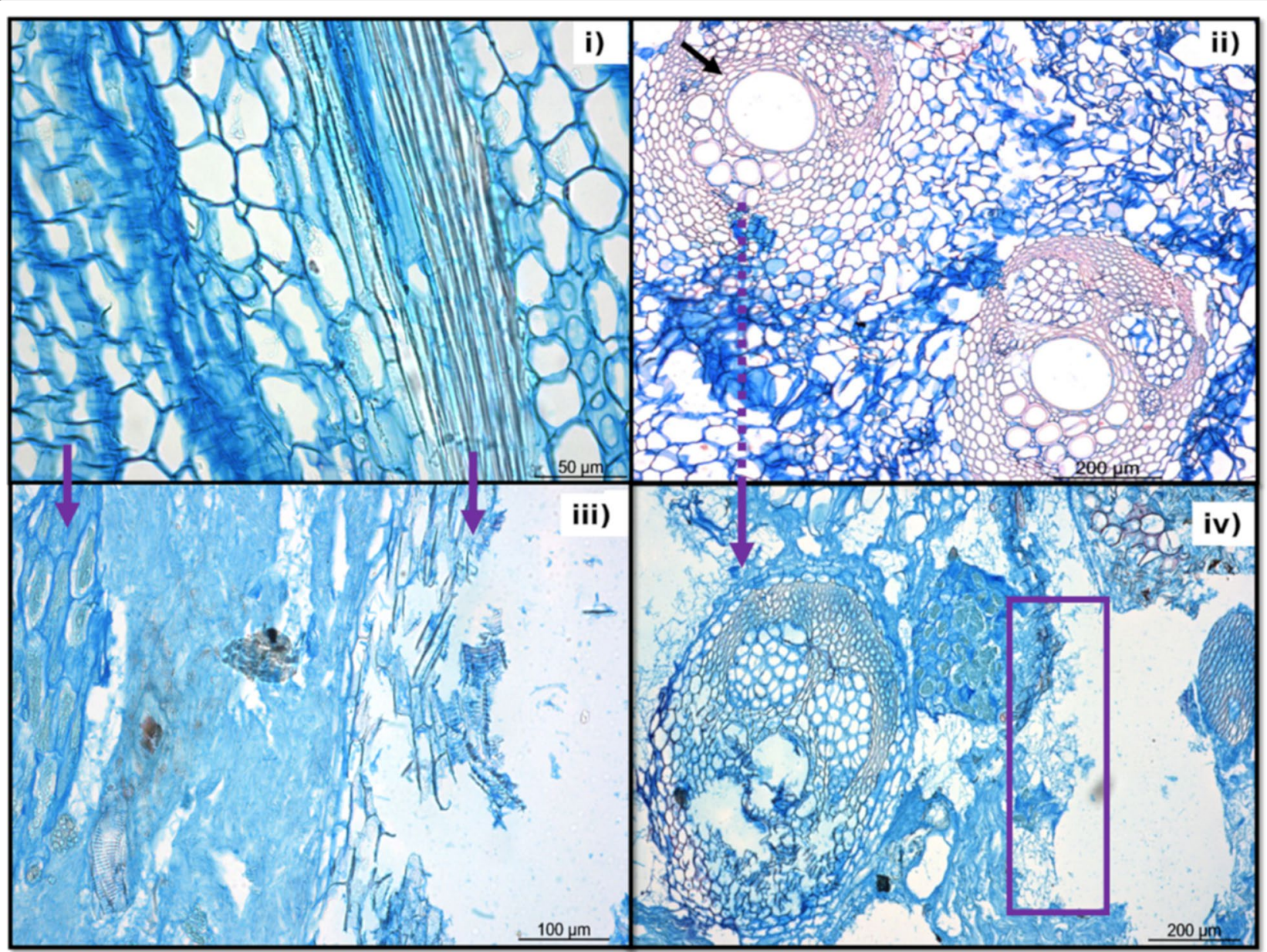

Fig. 5 Histological sections of peach palm sheaths (i) side $\times 400$ and (ii) cross-section $\times 100$. Cold-pressed mycelium-based composite side (iii) $\times 200$ and (iv) cross-section $\times 100$. The arrows indicate the degradation within the same region after the composite formation

in (iii-iv) and marked area in (iv) from Fig. 5], which are directly linked to $L$. edodes action; though, no fungus hyphae were found in the images.

The biodegradation of lignocellulosic materials by a fungus primarily occurs in an extracellular form, since they must initially be depolymerized to smaller compounds to be susceptible to be transported by the cell wall and intracellular fungi metabolism. Moreover, fungidegrading action occurs through penetration of their hyphae in the lumen of the plant cells (Rodríguez et al. 1997); afterwards, their hyphae produces a great diversity of extracellular metabolites, which then act by degrading the plant cell wall.

\section{Scanning electron microscopy (SEM) analysis}

The SEM images of the mycelium-based material were analysed on the cold-press composite, non-pressed also presented a similar structure-not shown-and their morphology exhibits an interconnected network, formed from L. edodes mycelium (Fig. 6i), and also presents their hyphae (Fig. 6ii, iii) which corresponds to the composite matrix.

The substrate particles are shown to be deeply hidden by the mycelium, containing a hypha with a diameter on the order of $1-5 \mu \mathrm{m}$ (Fig. 6ii, iii); they are either loosen due to degradation, or physically twisted with the mycelium, a morphology previously reported for mycelium-based composites (Liu et al. 2020). The fact that insufficient fungal had grown throughout the whole composite limits the bonding between the hyphae and the substrate, and is reported to be responsible for the limited mechanical performance (Islam et al. 2018; Liu et al. 2020).

Furthermore, the bind due to the network from the mycelium also affects its mechanical properties. The tensile resistance of mycelium-based composites is more influenced by failure of the binder than the substrate itself (Ziegler et al. 2016; Jones et al. 2018b). 


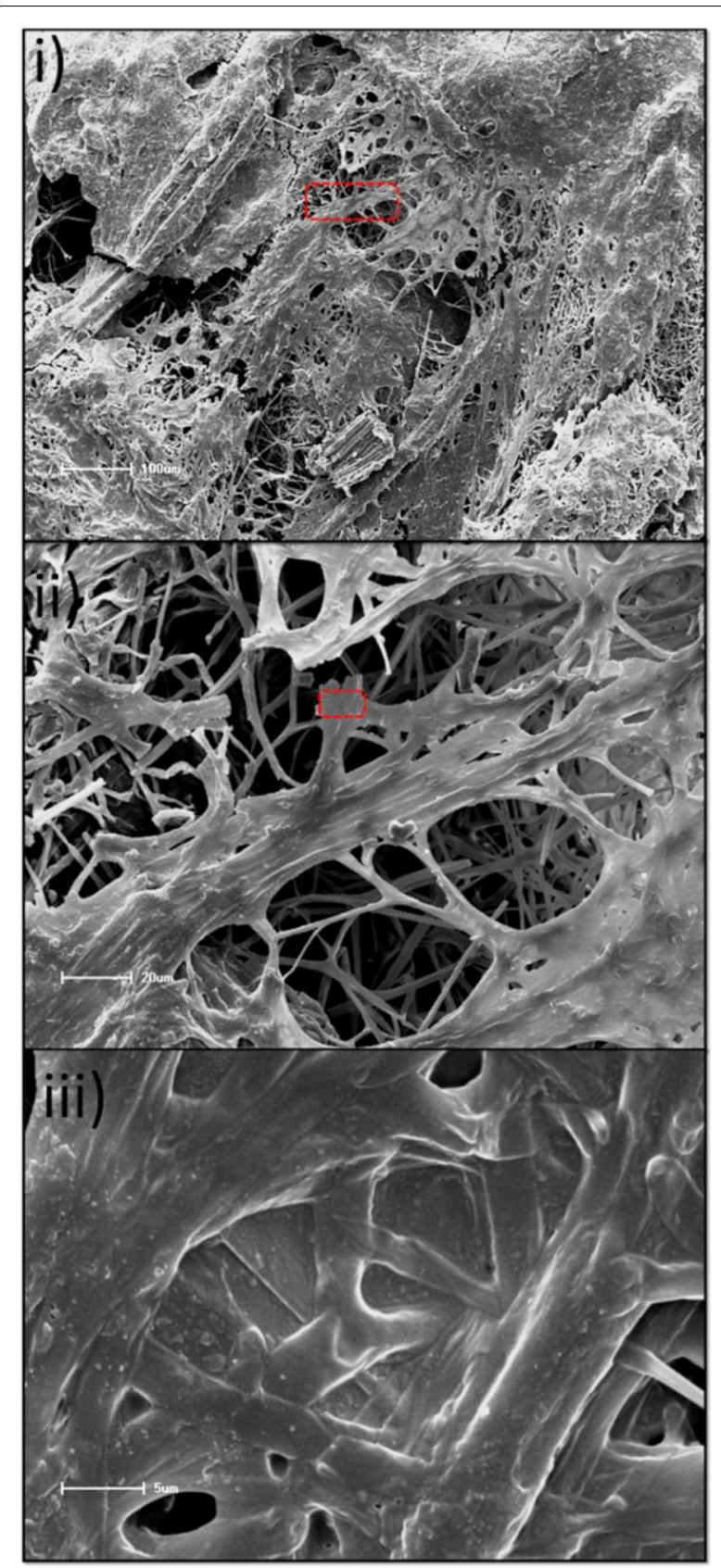

Fig. 6 Scanning electron microscope images of the mycelium-based composite cold-pressed at different resolutions at the same region, the dotted rectangles represent where the zoom was performed and are shown in ii and iii

\section{Compression test}

Compression tests revealed no rupture of the composite until the end of the test, with little deformation and greater resistance compared to polystyrene, and a commercial mycelium-based composite (Zeller and Zocher 2012).
The compressive stress-strain curve of the myceliumbased material presents a common behaviour, where at small compressive strains, the dominated response is related to be from the mycelium matrix, which presented elastic modulus on the order of 0.14-0.19 MPa. At larger strains, large number of fibre contact induces rapid stiffening (Islam et al. 2018) and the regime is dominated by the organic substrate particles (Haneef et al. 2017; Islam et al. 2017). These profiles were also similar to other works (Ziegler et al. 2016; Jones et al. 2017).

Compression test values presented small deviation on compression resistance tests, which can indicate that the mycelium developed homogeneously with a good bonding structure. Furthermore, it is important to mention that the compressive value obtained herein (Table 2) is within the region of polystyrene ( 0.23 compared to $0.15-0.7 \mathrm{MPa}$ ) and is characterized as rigid foam material (Xie et al. 2018). The time period of cultivation is also reported to affect the mechanical properties, whereas longer periods can increase it due to hyphae aggregation. By comparison, the cultivation period also influences the volume loss due to the drying of the substrate and hyphae collapsing (Haneef et al. 2017), though hyphae can colonize these vacancies left by water removal.

With a more nutritious substrate, the bonding and extent of their hyphae network is increased, while also increasing the material density, and is one of the main factors when failure occurs in these materials (Jones et al. 2017). Therefore, mycelium grown on substrate from residues to form mycelium-based materials is only suitable for foam like structures.

Researchers have been trying to conceive, with the overall properties of mycelium-based composites, industrial applications with computer-aided and design tools (Attias et al. 2019), possible applications suggested may be an insulating water container (Attias et al. 2020), insoles (Ziegler et al. 2016a, b), and indoor decoration (Zeller and Zocher 2012), among many others' complex geometries.

\section{Water absorption and swelling}

Water is an important criterion for many practical applications of mycelium-based products, thus, determining the performance under adverse conditions. In such cases, the water absorption values for the composite absorbed large quantities of water (245.1\%) (Table 2) with a thickness expansion of $21 \%$. The cold-pressed material had lower water absorbed and expansion, due to its compacted and rigid structure.

A major drawback on mycelium-based materials, compared to polystyrene, is their high-and fast water absorption. It is reported that they increase in weight by 40-580 wt\% in contact with water for 48-192 h (Jones et al. 
2020). This is due to their cellulose fibres having various hydroxyl groups, as well as its mycelium binder which is hydrophilic (Jones et al. 2017). The gel formed by these composites prevents dehydration of their hyphae (Antunes et al. 2020), allowing adhesion to other cells or surfaces. Moreover, the hyphae of $L$. edodes fungus is composed of $\beta$-glucans, chitin (Peniche-Covas et al. 1988), and proteins that are able to bind to others and form its own network, and these components are known to have high swelling values. Therefore, differences in water uptake from various mycelium-based materials are related to the difference in their chemical structure (Tacer-Caba et al. 2020).

\section{Thermal properties}

The DSC curves for the raw peach-palm sheaths, and the mycelium composite, exhibit (Fig. 7i) an increase in heat flow at $\sim 350{ }^{\circ} \mathrm{C}$, attributed to the exothermic event of cellulose decomposition. Compounds that are degraded at a temperature above $400{ }^{\circ} \mathrm{C}$, such as lignin, have exothermic profile, and because of the degradation that occurred within the mycelium, it contributed to the temperature stabilization before $500{ }^{\circ} \mathrm{C}$. The temperature profile presents degradation values similar to each individual fibre and matrix component of cellulose-based materials (Averous and Boquillon 2004).

Due to the substrate and the characteristics of the fungus, the thermal degradation is similar to most cellulosic materials. Furthermore, it can be seen that the non-pressed composite presented no significant variations at temperatures higher than $500{ }^{\circ} \mathrm{C}$ compared to cold-pressed. This might be related to the conditions that were grown the cold-pressed material, and may had not degraded all components at this specific temperature.

The thermal stability of the composites exhibits a threestage process in the thermal degradation, and follows the profile of the substrate-peach-palm sheaths-(Fig. 7ii, iii), the first stage from 35 to $100^{\circ} \mathrm{C}$ indicates evaporation of free and bonded water. The second stage is where the combustion started with a fast degradation rate within $250-350{ }^{\circ} \mathrm{C}$ associated with devolatilization process of the organic constituents of the substrate $(60 \%)$ (Jones et al. 2018a), and the final stage can be related to volatile matter that burned at such higher temperature, due to the air combustion, $450-600{ }^{\circ} \mathrm{C}$. Because of the denser, and more compact network found in the cold-pressed composite, it may have contributed to the increased values of the exothermic event at the final stage of $480{ }^{\circ} \mathrm{C}$.

The thermal profiles were similar to the peach-palm substrate, meaning that the fungus did not altered the thermal behaviour, and may be related to the substrate used as previously mentioned. Similar profiles for TG have been shown for T. multicolor fungus using rapeseed

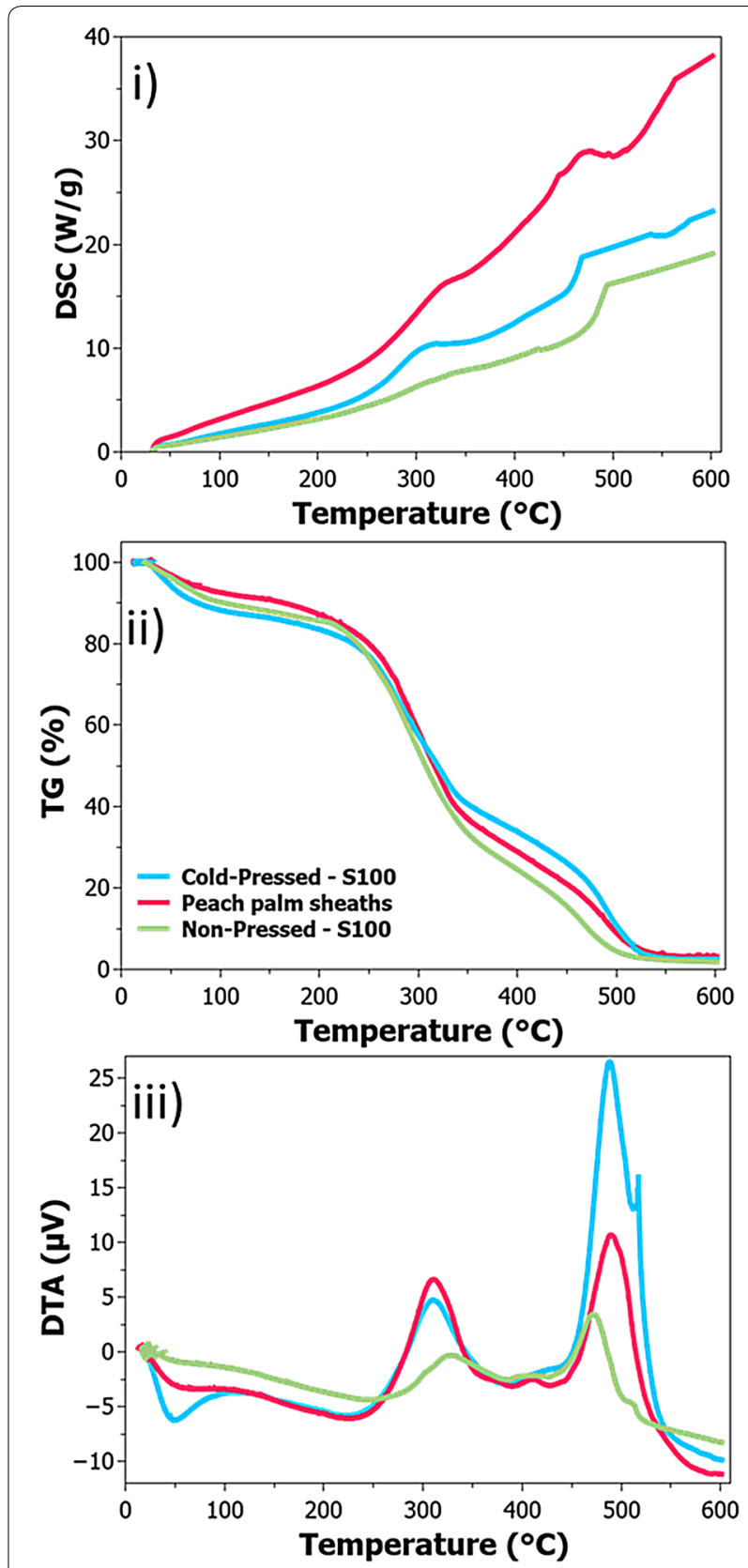

Fig. 7 Thermal analysis of the studied mycelium-based composites (i) DSC, (ii) TG, and (iii) DTA, within the comparisons are the pure raw peach-palm sheaths residue used to grow the fungus

straw, and the variation profile, whether cold-pressed and non-pressed, resulted in a similar graph (Appels et al. 2019). 


\section{Conclusions}

The physico-chemical and enzymatic activities for the mycelial growth of $L$. edodes in the peach-palm sheaths presented that the best feed source for mycelium growth and density was justified by the ratio content of carbon/nitrogen for mycelium to grow, while also due to the large source of available amino acids from the soy flour. This condition formed a well-developed composite within 12 days, with no visual differences from 20 days. However, soy flour from both inoculum, presented low enzymatic activity attributed to the fact that the mycelium grew in optimum conditions of $\mathrm{pH}$, moisture, and acceptable water activity; so, the enzymes were at the last digestive enzymes cycles. Contrarily, feed sources containing ammonium sulphate and potassium nitrate had a poor mycelial growth, with a decrease in $\mathrm{pH}$ due to the increased nitrogen source in the media; however, these treatments presented the highest enzymatic activities meaning that the mycelium had an improper condition to grow and was trying to establish a controllable environment to grow. The composite formed from the mycelium of $L$. edodes presented similar values of other mycelium-based composites on compressive strength and elastic modulus; however, even though the hyphae network completely filled the peach-palm residue from this mycelium, it did not fully degrade the residue and resulted in similar thermogravimetric results without differences in the overall thermal stability.

\section{Supplementary information}

Supplementary information accompanies this paper at https://doi. org/10.1186/s40643-020-00346-2.

Additional file 1.Additional figures.

\section{Acknowledgements}

The authors would like to acknowledge the financial support provided by Brazilian Agricultural Research Corporation (EMBRAPA). The author LBB Tavares is fellowship holder of the National Council for Scientific and Technological Development (CNPq).

\section{Authors' contributions}

GG wrote the manuscript and analysis of the data; ZCPS carried out the experiments; WL, LB, and CV, supervised and reviewed the manuscript. All authors read and approved the final manuscript.

\section{Funding}

Coordination for the Improvement of Higher Education Personnel_-Brazil (CAPES)_Finance Code 001.

\section{Availability of data and materials}

Data will be made available upon request.

\section{Ethics approval and consent to participate}

Not applicable.

\section{Consent for publication}

Not applicable.

\section{Competing interests}

The authors declare no conflicts of interest regarding the publication of this manuscript.

\section{Author details \\ 1 Programa de Pós-Graduação em Engenharia E Ciência dos Materiais-PIPE, Universidade Federal do Paraná, Curitiba, Paraná, Brazil. ${ }^{2}$ Materials Research Institute, Athlone Institute of Technology, Athlone, Ireland. ${ }^{3}$ Programa de Pós-Graduação Em Engenharia Ambiental-PPGEA, Universidade Regional de Blumenau, Blumenau, SC, Brazil. ${ }^{4}$ Embrapa Florestas, Colombo, Brazil.}

Received: 28 July 2020 Accepted: 22 October 2020

Published online: 31 October 2020

References

AOAC Official Methods of Analysis (2016) Official Methods of Analysis. Assoc Off Anal Chem Int 38:431

ASTM (1990) Standard practice for determining resistance of synthetic polymeric materials to fungi. ASTM G21-90. In: ASTM (ed) 1990 Annual Book of ASTM Standards (eds) ASTM. West Conshohocken, Pennsylvania, pp $845-851$

ASTM (2017) Standard Test Method for Measuring Compressive Properties of Thermal Insulations. ASTM C165-07. West Conshohocken, Pennsylvania ASTM D570-98 (2018) Standard Test for Water Absorption of Plastics. ASTM International: West Conshohocken, Pennsylvania.

Abhijith R, Ashok A, Rejeesh CR (2018) Sustainable packaging applications from mycelium to substitute polystyrene: a review. Mater Today Proc 5:2139-2145. https://doi.org/10.1016/j.matpr.2017.09.211

Antinori ME, Ceseracciu L, Mancini G, Heredia-Guerrero JA, Athanassiou A (2020) Fine-tuning of physicochemical properties and growth dynamics of mycelium-based materials. ACS Appl Bio Mater 3:1044-1051. https:// doi.org/10.1021/acsabm.9b01031

Antunes F, Marçal S, Taofiq O, Morais AM, Freitas AC, Ferreira IC, Pintado M (2020) Valorization of mushroom by-products as a source of value-added compounds and potential applications. Molecules 25:2672. https://doi. org/10.3390/molecules25112672

Appels FV, Camere S, Montalti M, Karana E, Jansen KM, Dijksterhuis J, Krijgsheld P, Wösten HA (2019) Fabrication factors influencing mechanical, moistureand water-related properties of mycelium-based composites. Mater Des 161:64-71. https://doi.org/10.1016/j.matdes.2018.11.027

Ates B, Koytepe S, Ulu A, Gurses C, Thakur VK (2020) Chemistry, structures, and advanced applications of nanocomposites from biorenewable resources. Chem Rev 120:9304-9362. https://doi.org/10.1021/acs.chemrev.9b00553

Attias N, Danai O, Abitbol T, Tarazi E, Ezov N, Pereman I, Grobman YJ (2020) Mycelium bio-composites in industrial design and architecture: comparative review and experimental analysis. J Clean Prod 246:119037. https:// doi.org/10.1016/j.jclepro.2019.119037

Attias N, Danai O, Tarazi E, Pereman I, Grobman YJ (2019) Implementing biodesign tools to develop mycelium-based products. Des J 22:1647-1657 https://doi.org/10.1080/14606925.2019.1594997

Averous L, Boquillon N (2004) Biocomposites based on plasticized starch: thermal and mechanical behaviours. Carbohydr Polym 56:111-122. https ://doi.org/10.1016/j.carbpol.2003.11.015

Bailey MJ, Biely P, Poutanen K (1992) Interlaboratory testing of methods for assay of xylanase activity. J Biotechnol 23:257-270. https://doi. org/10.1016/0168-1656(92)90074-J

Bellettini MB, Bellettini S, Vítola FM, Fiorda FA, Junior AM, Soccol CR (2017) Residual compost from the production of Bactris gasipaes Kunth and Pleurotus ostreatus as soil conditioners for Lactuca sativa'Veronica.' Semin Ciências Agrárias 38:581. https://doi.org/10.5433/1679-0359.2017v38n2p 581

Bentolila de Aguiar LV, Sales-Campos C, Melo de Carvalho CS, Almeida Minhoni MT, Nogueira de Andrade MC (2013) Uso de resíduos de madeiras e frutos da amazônia para o cultivo in vitro do cogumelo comestível shiitake. Interciencia 1:585-589 
Blanchette RA, Obst JR, Timell TE (1994) Biodegradation of compression wood and tension wood by white and brown rot fungi. Holzforschung-Int J Biol Chem Phys Technol Wood 48:34-42

Bolanho BC, Danesi EDG, del Pino BA (2014) Characterization of flours made from peach palm (Bactris gasipaes Kunth) by-products as a new food ingredient. J Food Nutr Res 53:51-59

British Standards Institution BSI (1993) Particleboards and fibreboards- Determination of swelling in thickness after immersion in water. Ref. no: EN 317: 1993 E. European Committee for Standardization.

Carvalho EA, Nunes LV, Goes LM, Silva EG, Franco M, Gross E, Uetanabaro AP, Costa AM (2018) Peach-palm ( Bactris gasipaes Kunth.) waste as substrate for xylanase production by Trichoderma stromaticum AM7. Chem Eng Commun 205:975-985. https://doi.org/10.1080/00986445.2018.1425208

Castellani A (1967) Maintenance and cultivation of common pathogenic fungi of man in sterile distilled water. Further Res J Trop Med Hyg 20:1-6

Chang ST (1987) Microbial biotechnology—Integrated studies on utilization of solid organic wastes. Resour Conserv 13:75-82. https://doi. org/10.1016/0166-3097(87)90051-4

Chicatto JA, Costa A, Nunes H, Helm CV, Tavares L (2014) Evaluation of hollocelulase production by Lentinula edodes (Berk.) Pegler during the submerged fermentation growth using RSM. Braz J Biol 74:243-250. https ://doi.org/10.1590/1519-6984.21712

Chicatto JA, Rainert KT, Gonçalves MJ, Helm CV, Altmajer-Vaz D, Tavares LB (2018) Decolorization of textile industry wastewater in solid state fermentation with Peach-Palm (Bactris gasipaes) residue. Braz J Biol 78:718-727. https://doi.org/10.1590/1519-6984.175074

Clement CR, Rodrigues DP, Alves-Pereira A, Mühlen GS, Cristo-Araújo MD, Moreira PA, Lins J, Reis VM (2016) Crop domestication in the upper Madeira River basin. Bol. do Mus. Para Emílio Goeldi Ciências Humanas 11:193-205

Couri S, Farias AX (1995) Genetic manipulation of Aspergillus niger for increased synthesis of pectinolytic enzymes. Rev Microbiol 26:314-317

EMBRAPA AleloMicro Open Data - BRM 055640. https://alelomicro.cenargen. embrapa.br/InterMicro/Passaporte/detalhes.xjs?ida=102706\&lang=en . Accessed 21 Jun 2020

Elisashvili V, Kachlishvili E, Asatiani MD (2015) Shiitake Medicinal Mushroom, Lentinus edodes (Higher Basidiomycetes) Productivity and LignocelluloIytic Enzyme Profiles during Wheat Straw and Tree Leaf Bioconversion. Int J Med Mushrooms 17:77-86. https://doi.org/10.1615/IntJMedMushroom S.V17.11.80

Elisashvili V, Penninckx M, Kachlishvili E, Tsiklauri N, Metreveli E, Kharziani T, Kvesitadze G (2008) Lentinus edodes and Pleurotus species lignocellulolytic enzymes activity in submerged and solid-state fermentation of lignocellulosic wastes of different composition. Bioresour Technol 99:457-462. https://doi.org/10.1016/j.biortech.2007.01.011

Franco TS, Potulski DC, Viana LC, Forville E, de Andrade AS, de Muniz GI (2019) Nanocellulose obtained from residues of peach palm extraction (Bactris gasipaes). Carbohydr Polym 218:8-19. https://doi.org/10.1016/j.carbp ol.2019.04.035

Gaitán-Hernández R, Esqueda M, Gutiérrez A, Beltrán-García M (2011) Quantitative changes in the biochemical composition of lignocellulosic residues during the vegetative growth of Lentinula edodes. Braz J Microbiol 42:30-40. https://doi.org/10.1590/S1517-83822011000100004

Glass N (2004) Hyphal homing, fusion and mycelial interconnectedness. Trends Microbiol 12:135-141. https://doi.org/10.1016/j.tim.2004.01.007

Haneef M, Ceseracciu L, Canale C, Bayer IS, Heredia-Guerrero JA, Athanassiou A (2017) Advanced materials from fungal mycelium: fabrication and tuning of physical properties. Sci Rep 7:41292. https://doi.org/10.1038/srep4 1292

Helm CV, Raupp DDS, dos Santos ÁF (2013). Development of peach palm fibrous flour from the waste generated by the heart of palm agribusiness -. https://doi.org/10.4025/actascitechnol.v36i1.17165.ActaSciTechnol3 6:10.4025/actascitechnol.v36i1.17165

Hermann KL, Costa A, Helm CV, Lima EA, Tavares LB (2013) Expression of manganese peroxidase by Lentinula edodes and Lentinula boryana in solid state and submerged system fermentation. An Acad Bras Cienc 85:965-973. https://doi.org/10.1590/50001-37652013000300009

IBGE (2019) Agricultural Production - Permanent Crops | Peach Palm. https:// cidades.ibge.gov.br/brasil/pesquisa/15/11863. Accessed 6 Oct 2020
Islam MR, Tudryn G, Bucinell R, Schadler L, Picu RC (2017) Morphology and mechanics of fungal mycelium. Sci Rep 7:13070. https://doi.org/10.1038/ s41598-017-13295-2

Islam MR, Tudryn G, Bucinell R, Schadler L, Picu RC (2018) Mechanical behavior of mycelium-based particulate composites. J Mater Sci 53:16371-16382. https://doi.org/10.1007/s10853-018-2797-z

Jones M, Bhat T, Huynh T, Kandare E, Yuen R, Wang CH, John S (2018a) Wastederived low-cost mycelium composite construction materials with improved fire safety. Fire Mater 42:816-825. https://doi.org/10.1002/ fam.2637

Jones M, Bhat T, Kandare E, Thomas A, Joseph P, Dekiwadia C, Yuen R, John S, Ma J, Wang CH (2018b) Thermal degradation and fire properties of fungal mycelium and mycelium - biomass composite materials. Sci Rep 8:17583. https://doi.org/10.1038/s41598-018-36032-9

Jones M, Huynh T, Dekiwadia C, Daver F, John S (2017) Mycelium composites: a review of engineering characteristics and growth kinetics. J Bionanosci 11:241-257. https://doi.org/10.1166/jbns.2017.1440

Jones M, Mautner A, Luenco S, Bismarck A, John S (2020) Engineered mycelium composite construction materials from fungal biorefineries: a critical review. Mater Des 187:108397. https://doi.org/10.1016/j.matde s.2019.108397

Kraus JE, Arduin M (1997) Manual básico de métodos em morfologia vegetal. EDUR Seropédica, Rio de Janeiro

Kües U, Liu Y (2000) Fruiting body production in basidiomycetes. Appl Microbiol Biotechnol 54:141-152

Leonowicz A, Wojtas-Wasilewska M, Rogalski J, Luterek J (1991) Higher fungi as a potential feed and food source from lignocellulosic wastes. Stud Environ Sci 42:229-255. https://doi.org/10.1016/S0166-1116(08)70331-5

Lin Y, Ge X, Liu Z, LiY (2015) Integration of Shiitake cultivation and solid-state anaerobic digestion for utilization of woody biomass. Bioresour Technol 182:128-135. https://doi.org/10.1016/j.biortech.2015.01.102

Liu R, Li X, Long L, Sheng Y, Xu J, Wang Y (2020) Improvement of mechanical properties of mycelium/cotton stalk composites by water immersion. Compos Interfaces. https://doi.org/10.1080/09276440.2020.1716573

Lutz IA (2005) Normas analíticas do Instituto Adolfo Lutz. Métodos Físicoquímicos para Análise de Alimentos do Instituto Adolfo Lutz (4th ed.) IAL, Brasília.

Mata G, Salmones D, Pérez-Merlo R (2016) Hydrolytic enzyme activities in shiitake mushroom (Lentinula edodes) strains cultivated on coffee pulp. Rev Argent Microbiol 48:191-195. https://doi.org/10.1016/j.ram.2016.05.008

Matos MP, Teixeira JL, Nascimento BL, Griza S, Holanda FS, Marino RH (2019) Production of biocomposites from the reuse of coconut powder colonized by Shiitake mushroom. Ciência e Agrotecnologia. https://doi. org/10.1590/1413-7054201943003819

Miller GL (1959) Use of dinitrosalicylic acid reagent for determination of reducing sugar. Anal Chem 31:426-428. https://doi.org/10.1021/ac60147a030

Mora-Urpí J, Weber JC, Clement CR (1997) Bactris gasipaes Kunth. Institute of Plant Genetics and Crop Plant Research—IPK: Gatersleben, Germany/ International Plant Genetic Resources Institute_IPGRI: Rome, Italy, 1997; Promoting the conservation and use of underutilized and neglected crops, Volume 20, p. 83.

de Oliveira KT, Patreze CM, Salgueiro F (2019) High-resolution melting analysis for testing the authenticity of fresh and canned heart of palm, an economically important non-timber forest product from the Neotropics. Plant Ecol Divers 12:181-187. https://doi.org/10.1080/17550 874.2019.1596173

Pandey A, Soccol CR, Mitchell D (2000) New developments in solid state fermentation: I-bioprocesses and products. Process Biochem 35:1153-1169. https://doi.org/10.1016/S0032-9592(00)00152-7

Pedri ZC, Lozano LM, Hermann KL, Helm CV, Peralta RM, Tavares LB (2015) Influence of nitrogen sources on the enzymatic activity and grown by Lentinula edodes in biomass Eucalyptus benthamii. Braz J Biol 75:940-947. https://doi.org/10.1590/1519-6984.03214

Peniche-Covas C, Jiménez MS, Núñez A (1988) Characterization of silverbinding chitosan by thermal analysis and electron impact mass spectrometry. Carbohydr Polym 9:249-256. https://doi.org/10.1016/01448617(88)90043-4

Philippoussis A, Diamantopoulou P, Papadopoulou K, Lakhtar H, Roussos S, Parissopoulos G, Papanikolaou S (2011) Biomass, laccase and endoglucanase 
production by Lentinula edodes during solid state fermentation of reed grass, bean stalks and wheat straw residues. World J Microbiol Biotechnol 27:285-297. https://doi.org/10.1007/s11274-010-0458-8

Queiroz EC, Marino RH, da Eira AF (2004) Mineral supplementation and productivity of the Shiitake mushroom on eucalyptus logs. Sci Agric 61:260-265. https://doi.org/10.1590/S0103-90162004000300003

Rabelo SC, da Costa AC, Vaz Rossel CE (2015) Industrial Waste Recovery. In: Sugarcane. Elsevier, pp 365-381

Rodríguez J, Ferraz A, Nogueira RF, Ferrer I, Esposito E, Durán N (1997) Lignin biodegradation by the ascomycete Chrysonilia sitophila. Appl Biochem Biotechnol 62:233-242. https://doi.org/10.1007/BF02787999

Rughoonundun H, Mohee R, Holtzapple MT (2012) Influence of carbon-tonitrogen ratio on the mixed-acid fermentation of wastewater sludge and pretreated bagasse. Bioresour Technol 112:91-97. https://doi. org/10.1016/j.biortech.2012.02.081

Seben LDL, De-Paula IC, Viana SG (2012) Análise do processo de beneficiamento da Palmeira Real da Austrália (palmito em conserva) para determinação das variáveis que influenciam as operações de valorização de seus resíduos. Prod Produção. https://doi.org/10.22456/1983-8026.24238

Singha AS, Thakur VK (2009) Fabrication and characterization of S. cilliare fibre reinforced polymer composites. Bull Mater Sci 32:49-58. https://doi. org/10.1007/s12034-009-0008-x

de Siqueira FG, de Siqueira AG, de Siqueira EG, Carvalho MA, Peretti BM, Jaramillo PM, Teixeira RS, Dias ES, Félix CR, Ferreira Filho EX (2010) Evaluation of holocellulase production by plant-degrading fungi grown on agroindustrial residues. Biodegradation 21:815-824. https://doi.org/10.1007/ s10532-010-9346-z

Song CH, Cho KY, Nair NG (1987) A synthetic medium for the production of submerged cultures of Lentinus Edodes. Mycologia 79:866-876. https:// doi.org/10.1080/00275514.1987.12025475

Stella T, Covino S, Čvančarová M, Filipová A, Petruccioli M, D'Annibale A Cajthaml T (2017) Bioremediation of long-term PCB-contaminated soil by white-rot fungi. J Hazard Mater 324:701-710. https://doi.org/10.1016/j. jhazmat.2016.11.044
Tacer-Caba Z, Varis JJ, Lankinen P, Mikkonen KS (2020) Comparison of novel fungal mycelia strains and sustainable growth substrates to produce humidity-resistant biocomposites. Mater Des 192:108728. https://doi. org/10.1016/j.matdes.2020.108728

Tanaka M, Taniguchi M, Matsuno R, Kamikubo T (1981) Purification and properties of cellulases from Eupencillium javanicum: studies on the re-utilization of cellulosic resources (VII). J Ferment Technol 59:177-183

Teixeira JL, Matos MP, Nascimento BL, Griza S, Holanda FS, Marino RH (2018) Production and mechanical evaluation of biodegradable composites by white rot fungi. Ciência e Agrotecnologia 42:676-684. https://doi. org/10.1590/1413-70542018426022318

Wood TM, Garcia-Campayo V (1990) Enzymology of cellulose degradation. Biodegradation 1:147-161. https://doi.org/10.1007/BF00058833

Xie Q, Li F, Li J, Wang L, Li Y, Zhang C, Xu J, Chen S (2018) A new biodegradable sisal fiber-starch packing composite with nest structure. Carbohydr Polym 189:56-64. https://doi.org/10.1016/j.carbpol.2018.01.063

Zeller P, Zocher D (2012) Ecovative's breakthrough biomaterials. Fungi Mag 5:51-56

Zenni RDS, Helm CV, Tavares LBB (2018) Cascas do processamento de palmito para uso na alimentação humana: uma abordagem socioambiental. Rev Gestão Sustentabilidade Ambient 7:276. https://doi.org/10.19177/rgsa. v7e22018276-299

Ziegler AR, Bajwa SG, Holt GA, Mcntyre G (2016) Evaluation of physicomechanical properties of mycelium reinforced green biocomposites made from cellulosic fibers. Appl Eng Agric 32:931-938. https://doi. org/10.13031/aea.32.11830

Ziegler AR, Bajwa SG, Holt GA, McIntyre G, Bajwa DS (2016) Evaluation of physico-mechanical properties of mycelium reinforced green biocomposites made from cellulosic fibers. Eng. Agric.

\section{Publisher's Note}

Springer Nature remains neutral with regard to jurisdictional claims in published maps and institutional affiliations.

\section{Submit your manuscript to a SpringerOpen ${ }^{\circ}$ journal and benefit from:}

- Convenient online submission

- Rigorous peer review

- Open access: articles freely available online

- High visibility within the field

- Retaining the copyright to your article

Submit your next manuscript at $\boldsymbol{\nabla}$ springeropen.com 